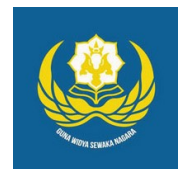

Jurnal Analogi Hukum

Journal Homepage: https://ejournal.warmadewa.ac.id/index.php/analogihukum

\title{
Kewenangan Pengadilan Negeri Memutus Perkara Praperadilan Mengenai Tidak Sahnya Penetapan Tersangka
}

\author{
Ida Ayu Wayan Widyastuti*, Anak Agung Sagung Laksmi Dewi dan I Nyoman Gede Sugiartha \\ Fakultas Hukum, Universitas Warmadewa, Denpasar, Bali-Indonesia \\ *iawidyastuti@gmail.com
}

\begin{abstract}
How To Cite:
Widyastuti, I. A. W., Dewi, A. A. S. L., \& Sugiartha, I. N. G. (2020). Kewenangan Pengadilan Negeri Memutus Perkara Praperadilan Mengenai Tidak Sahnya Penetapan Tersangka. Jurnal Analogi Hukum. 2(3). 351-355. Doi: https://doi.org/10.22225/ah.2.3.2519.351-355

Abstract-Pre-trial institutions have the purpose of providing certainty and controlling abuse of authority by law enforcement officials. Forced measures such as arrest, detention, search, confiscation, prosecution and determination of suspects carried out in accordance with the provisions of legislation are often used by law enforcement officials to obtain evidence. The problem raised is how is the regulation of the authority of the district court to decide the pretrial lawsuit? How is the procedure for hearing a pretrial hearing? This research is a study that examines legislation as an effort to answer existing problems. The authority of the district court checks and decides on a pretrial case in accordance with what is stipulated in article 77 of the Criminal Procedure Code. While the procedure for examining pretrial hearings is the procedure that must be fulfilled, namely Submission of pretrial applications, Application for registration in pretrial cases, Head of District Court Immediately Appoints Judges and Registrars, Examinations are conducted with a single judge. Law enforcement agencies, in this case the police as one of the justice enforcement agencies must be carried out by its members responsibly and carried out wholeheartedly and in accordance with the laws and regulations. The community as being protected must have a critical nature and at least know the inspection procedures in the police so that they understand their rights when dealing with the law .
\end{abstract}

Keywords: Authority to Decide; Pre-trial; Criminal.

\begin{abstract}
Abstrak-Praperadilan memiliki tujuan untuk memberikan kepastian dan mengontrol penyalahgunaan wewenang oleh aparat penegak hukum. Upaya paksa seperti penangkapan, penahanan, penggeledahan, penyitaan, penuntutan, dan penetapan tersangka yang dilakukan tidak sesuai dengan ketentuan peraturan perundang-undangan sering kali digunakan oleh aparat penegak hukum untuk dapat memperoleh alat-alat bukti. Permasalahan yang diangkat adalah bagaimanakah pengaturan kewenangan pengadilan negeri memutus gugatan praperadilan? Bagaimanakah tata cara pemeriksaan sidang praperadilan? Penelitian ini adalah merupakan penelitian yang mengkaji aturan perundang-undangan sebagai upaya untuk menjawab permasalahan yang ada. Kewenangan pengadilan negeri memeriksa dan memutus suatu perkara praperadilan sesuai dengan yang diatur dalam pasal 77 KUHAP. Sedangkan tata cara pemeriksaan sidang praperadilan adapun prosedur yang harus dipenuhi yaitu Pengajuan permohonan praperadilan, Permohonan registrasi dalam perkara praperadilan, ketua Pengadilan Negeri Segera Menunjuk Hakim dan Panitera, pemeriksaan dilakukan dengan hakim tunggal. Lembaga penegak hukum, dalam hal ini kepolisian sebagai salah satu lembaga penegak keadilan harus dijalankan oleh anggotanya dengan bertanggungjawab dan dilaksanakan dengan sepenuh hati serta sesuai dengan peraturan perundang-undangan. Masyarakat sebagai yang diayomi harus memiliki sifat kritis dan paling tidak mengetahui prosedur pemeriksaan dikepolisian sehingga paham akan hak-haknya apabila berurusan dengan hukum.
\end{abstract}

Kata kunci: Kewenangan Memutus; Praperadilan; Pidana

\section{Pendahuluan}

Indonesia merupakan Negara hukum dengan Pancasila sebagai dasar negara dan Undang-undang Dasar 1945 sebagai hukum yang berkedudukan paling tinggi. Aparat penegak hukum di Indonesia haruslah melindungi dan mengayomi masyarakat guna terciptanya rasa aman dan keadilan. Undangundang Nomor 2 Tahun 2002 dijelaskan bagaimana tugas, fungsi serta wewenang aparat kepolisian dalam pencarian barang bukti agar 
dapat menetapkan seorang tersangka. Namun dalam mengumpulan bukti-bukti tersebut harus tetap diperhatikan asas praduga tak bersalah yang diatur dalam penjelasan umum KUHAP butir ke 3 huruf $\mathrm{C}$ dan Pasal 8 ayat 1 Undangundang Kekuasaan Kehkiman dimana seseorang tidak boleh dikatakan bersalah sebelum adanya penetapan oleh pengadilan. Menurut Yahya Harahap asas praduga tak bersalah ditinjau dari teknis yuridis ataupun dari segi teknis penyidikan dinamakan "prinsip akusatur" atau accusatory procedure (accusatorial system". Prinsip akusatur menempatakan kedudukan tersangka atau terdakwa dalam setiap tingkat pemeriksaan adalah subjek bukan sebagai objek pemeriksaan, karena itu tersangka atau terdakwa harus didudukkan dan diberlakukan dalam kedudukan manusia yang mempunya harkat martabat harga diri, yang menjadi objek pemeriksaan dalam prinsip akusatur adalah "kesalahan" (tindak pidana) yang dilakukan tersangka atau terdakwa (Harahap, 2016).

Tentunya dalam mengumpulkan alat bukti tersebut terdapat suatu upaya paksa yang dilakukan kepolisian berupa penggeledahan, penangkapan, penahanan, penyitaan, penuntutan dan penetapan tersangka yang sering dilakukan dengan melanggar ketentuan yang berlaku dianggap telah melanggar hak asasi yang dimiliki oleh seseorang. Sehingga diberlakukannya Undang-undang Nomor 8 Tahun 1981 Tentang Hukum Acara Pidana yang menggantikan HIR. Hal tersebut dapat merubah proses hingga upaya seorang terdakwa untuk mendapatkan suatu keadilan dikarenakan perilaku aparat penegak hukum yang sewenangwenang kepada lembaga yang disebut Praperadilan. praperadilan merupakan upaya control dari tindakan atau peristiwa yang berbanding terbalik dengan undangundang.Diharapkan dengan adanya Praperadilan ini dapat mencegah tindakantindakan yang bertentang dengan undangundang.

Pada penelitian (Nugroho, 2020) mengungkapkan Sah tidaknya penetapan tersangka sebagai objek Praperadilan sebelum adanya Putusan Mahkamah Konstitusi Nomor 21/PUU-XII/2014 ada yang ditolak dan ada yang diterima sehingga menimbulkan ketidakpastian hukum. Penelitian lainnya mengungkapkan melalui putusan Mahkamah Konstitusi (MK) pada tanggal 28 April 2015 Nomor 21/PUU-XII/2014 (Putusan MK) telah memutus diantaranya bahwa lingkup kewenangan praperadilan yang diatur dalam Pasal 77 huruf (a) UU HAP mencakup juga sah atau tidaknya penetapan tersangka (halaman 110 Putusan MK). Putusan MK ini artinya telah memperluas kewenangan praperadilan itu sendiri, yang dahulu mencakup sah atau tidaknya penangkapan, penahanan, penghentian penyidikan, atau penghentian penuntutan, saat ini diperluas diantaranya pula mencakup mengenai memeriksa dan memutus sah atau tidaknya penetapan status tersangka seseorang (Rahman, 2015).

Dari uraian diatas tersebut maka dapat dirumuskan permasalan yakni pengaturan kewenangan pengadilan negeri memutus gugatan praperadilan dan tata cara pemeriksaan sidang praperadilan. Penlitian ini bertujuan untuk dapat mengetahui pengaturan kewenangan pengadilan negeri memutus gugatan praperadilan dan untuk dapat mengetahui tata cara pemeriksaan sidang praperadilan.

\section{Metode}

Tipe penelitian yang digunakan adalah penelitian normatif yang dilakukan dengan meneliti bahan hukum primer yang terdiri dari peraturan perundang-undangan dan bahan hukum sekunder yang berkaitan dengan topik permasalahan baik dalam bentuk literatur hukum yang ditulis oleh para ahli hukum dan buku-buku yang dapat memberikan penjelasan mengenai bahan hukum primer. Pendekatan masalah menggunakan pendekatan yang berasal dari peraturan perundang-undangan yang berkaitan dengan praperadilan agar terdapat peraturan yang jelas.Pengumpulan bahan hukum primer dan bahan hukum sekunder dilakukan dengan study kepustakaan yaitu membaca, mencatat, mengkaji, menelaah, dimana semua bahan hukum yang sudah diperoleh diolah dan dijabarkan dalam bentuk uraian untuk dapat memperoleh suatu jawaban dari permasalahan sebagai hasil dari penelitian.

\section{Hasil Penelitian dan Pembahasan}

\section{Pengaturan Kewenangan Pengadilan Negeri Memutus Gugatan Praperadilan}

Praperadilan adalah suatu upaya yang dilakukan oleh pengadilan negeri untuk memeriksa dan memutus tentang keabsahan penangkapan, penahanan, penghentian penyidikan, penghentian penuntutan dan memutus permintaan ganti kerugian dan rehabilitasi yang dimana perkara pidananya tidak diajukan ke muka sidang pengadilan negeri atas permintaan tersangka atau terdakwa atau keluarga dan atau penasehat hukumnya 
(Prints, 1993). Praperadilan ialah wewenang yang dimiliki oleh pengadilan negeri untuk dapat memeriksa dan memutus suatu permohonan praperadilan sesuai dengan pasal 1 butir 10 KUHAP. Sah atau tidaknya dilakukan suatu penangkapan atau penahanan, adanya permintaan penghentian penyidikan atau penuntutan yang dapat dilakukan oleh penyidik atau penuntut umum atas pihak ketiga yang berkepentingan yang memuat alasan penghentian penyidikan oleh penyidik atau penuntut umum serta adanya suatu permintaan ganti kerugian dan rehabilitasi dikarenakan adanya penggeledahan dan penyitaan yang dilakukan dengan cara yang tidak sesuai oleh penyidik atau penuntut umum dapat diajukan oleh tersangka melaui praperadilan adalah wewenang dari pengadilan negeri untuk memeriksa dan memutus suatu perkara praperadilan yang diajukan.

Dalam pasal 77 KUHAP menyatakan kewenangan dari pengadilan negeri untuk memeriksa dan memutus praperadilan ialah sah atau tidaknya penangkapan, penahanan, penghentian penyidikan atau penghentian penuntutan serta ganti kerugian dan rehabilitasi. Penangkapan menurut pasal 1 butir 20 KUHAP merupakan sesuatu yang dilakukan oleh tim penyidik dimana terdakwa atau tersangka ditahan sementara untuk memperlancar proses penyidikan guna mengumpulkan barang bukti. Menurut ketentuan pasal 1 butir 21 KUHAP penahanan ialah dimana terdakwa ditahan di tempat tertentu yang mana kebebasannya untuk bergerak dibatasi. Penghentian penyidikan atau penuntutan dilakukan apabila menurut penyidik terdakwa tersebut dirasa kurang memiliki bukti atau tindakan yang dilakukan terdakwa bukan termasuk tindak pidana. Pengajuan tuntutan ganti kerugian dan rehabilitasi yang diajukan oleh tersangka atau ahli warisnya merupakan wujud perlindungan terhadap hak asasi dan harkat martabat dikarenanakan pada saat proses pemeriksaan oleh apparat penegak hukum terjadi tindakan-tindakan yang yang tidak sesuai dengan ketentuan yang berlaku. Ganti kerugian adalah hak seseorang dalam untuk mendapat pemenuhan atas tuntutan dalam bentuk sejumlah uang dikarenakan kekeliruan atas orang yang ditangkap, ditahan dan diadili. Pengajuan tuntutan rehabilitasi adalah hak untuk mendapatkan kembali kehormatan dan harkat martabatnya di dalam masyarakat karena adanya kekeliruan dalam proses penyidikan, dimana tidak ditemukannya bukti yang cukup, tuntutan rehabailitasi biasanya untuk memperbaiki nama baik oramg yang ditetapkan menjadi tersangka dan nama baik keluarga dari orang tersebut.
Jika dalam pasal 77 KUHAP kewenangan praperadilan hanya terbatas pada sah atau tidaknya penangkapan, penahanan serta penghentian penyidikan atau penuntutan, dalam putusannya mahkamah konstitusi memperluas obyek gugatan praperadilan melalui putusan nomor 21/PUU-XII/2014 mengenai sah atau tidaknya penetapan tersangkadikarenakan didalam KUHAP tidak dapat memberikan pengawasan dan keseimbangan terhadap tindakan penyidik yang tidak sesuai dengan aturan-aturan yang berlaku. Pada dasarnya tidak ada yang menginginkan untuk ditetapkan menjadi seorang tersangka meskipun ia telah melakukan suatu perbuatan yang melanggar undang-undang. Untuk dapat mendapatkan alat bukti dalam suatu tindak pidana, dimana seseorang yang melakukan suatu tindak pidana terlebih dahulu ditetapkan menjadi tersangka agar penyidik dapat memperoleh alat bukti untuk memperkuat status tersangka. Putusan mahkamah konstitusi memerikan wewenang lebih yang dimiliki oleh praperadilan tentang jumlah alat bukti untuk dapat menetapkan seseorang menjadi tersangka harus didasarkan pada bukti permulaan yang cukup. Putusan mahkamah konstitusi memungkinkan tersangka untuk mengajukan tuntutan kepada penegak hukum yang bertindak tidak sesuai undangundang selama proses penyidikan. Hal ini tentu diharapkan dapat menciptakan upaya penegakan hukum yang tetap memperhatikan hak asasi seseorang.

\section{Tata Cara Pemeriksaan Sidang Praperadilan}

Dalam pemeriksaan sidang praperadilan diawali dengan pemeriksaan kelengkapan administrasi. Pemeriksaan dalam sidang praperadilan hanyalah masalah formil dari suatu tindakan yang dilakukan oleh penyidik atau penuntut umum (Prints, 2002). Adapun beberapa prosedur dalam pengajuan gugatan praperadilan yaitu:

\section{Pengajuan Permohonan Praperadilan}

Permohonan praperadilan ditujukan kepada ketua pengadilan negeri yang meliputi wilayah hukumnya. Dalam pengajuan permohonan gugatan praperadilan harus berisi keterangan lengkap yang memuat nama, alamat, pekerjaan, serta data diri lainnya, persyaratan materiil berisi dasar alasan dan dasar hukum (fundamentum petendi/ posita) yang menggambarkan dan menguraiakan terlebih dahulu tentang kejadian perkara serta alasanalasan berdasarkan hukum yang dijadikan dasar untuk mengajukan suatu tuntutan atau permohonan agara diputus oleh hakim 
praperadilan. Dalam pengajuan gugatan praperadilan harus diperhatikan siapa saja pihak yang dapat mengajukan. Pihak-pihak yang dapat mengajukan adalah:

a. Tersangka, keluarganya, atau kuasanya

Tersangka yang dapat mengajukan praperadilan adalah tersangka yang salah tangkap, salah tahan, yang merupakan human error selama proses penyidikan oleh penyidik.

Keluarga yang dimaksud adalah merupakan keluarga dengan hubungan vertical dan horizontal yang dapat dibuktikan secara formal dengan tersangka. sedangkan kusanya adalah orang yang mendapat kuasa dari tersangka atau keluarganya untuk mengajukan permohonan praperadilan.

b. Penuntut umum atu pihak ketiga yang berkepentingan

Pasal 80 KUHAP memberikan hak kepada penuntut umum dan pihak ketiga yang berkepentingan untuk mengajukan pemeriksaan mengenai sah atau tidaknya penghentian penyidikan oleh penyidik.

c. Penyidik atau pihak ketiga yang berkepentingan

Penyidik atau pihak ketiga yang berkepentingan dapat mengajukan permintaan pemeriksaan sah atau tidaknya penghentian penuntutan yang dilakukan oleh penuntut umum.

\section{Permohonan Registrasi dalam Perkara Praperadilan}

Setelah permohonan pengajuan praperadilan diterima oleh panitera yang kemudian akan langsung diregister dalam perkara praperadilan yang dipisahkan dengan perkara pidana biasa. Panitera merupakan unsur pimpinan yang bertugas untuk mencatat berita acara didalam persidangan dari dimulaimya proses persidangan sampai adanya putusan memerlukan kecerdasan kerja dalam penataan administrasi, baik administrasi yang dilaksanakan secara manual maupun dengan system komputerisasi.

\section{Ketua Pengadilan Negeri Menunjuk Hakim dan Panitera}

Ketua pengadilan negeri bertanggung jawab atas terselenggaranya administrasi pada perkara di dalam pengadilan tersebut, ketua pengadilan harus melaksanakan pengawasan terhadap penyelenggaraan peradilan di daerah hukumnya, ketua pengadilan menunjuk hakim untuk memimpin proses peradilan suatu perkara, ketua pengadilan negeri menyerahkan pelaksanaan administrasi kepada panitera sehingga agar proses pemeriksaan praperadilan dapat berjalan dengan baik penunjukan hakim dilakukan segera setelah permohonan diterima, dikarenakan permohonan praperadilan harus sudah memiliki putusan dalam waktu 7 hari. Sidang praperadilan di pimpin oleh hakim tunggal.

Adapun acara pemeriksaan sidang praperadilan yaitu:

a. Penetapan Hari sidang dan Jangka Waktu Persidangan Praperadilan

Praperadilan pada dasarnya dilakukan dengann acara cepat. Dalam jangka waktu 3 hari setelah permohonan diterima hakim harus menetapkan hari dan tanggal persidangan. Pada hari penetapan persidangan hakim akan menyampaikan panggilan kepada para pihak yang menjadi termohon dan pemohon.

\section{b. Tata Cara Persidangan}

Pemeriksaan dalam sidang praperadilan bukan hanya terhadap pemohon tapi juga terhadap penyidik dalam kepolisian maupun penuntut umum tergantung isi dari surat permohonan yang diajukan. Proses praperadilan mirip dengan pemeriksaan sidang perkara perdata, dalam hal ini pemohon sebagai penggugat dan termohon sebagai tergugat. Dalam persidangan praperadilan ada beberapa tahap pemeriksaan yakni, pemeriksaan surat kuasa dan pembacaan isi dari surat permohonan yang diajukan, pemanggilan saksi-saksi dan pemeriksaan bukti-bukti yang diajukan dalam sidang permohonan tersebut. Hakim kemudian didalam persidangan akan mendengarkan keterangan dari pemohon atau termohon untuk dapat mempertimbangkan dalam memberikan putusan terhadap permohonan praperadilan tersebu.

\section{c. Putusan Pengadilan Praperadilan}

Bentuk putusan praperadilan cukup sederhana tanpa mengurangi isi pertimbangan yang jelas berdasarkan hukum dan undangundang. Bentuk putusan praperadilan hampir mirip dengan putusan volunteer dalam acara perdata, putusan praperadilan juga bersifat deklator yang berisikan pernyataan tentang sah atau tidaknya penangkapan, penahanan penggeledahan atau penyitaan. Putusan praperadilan tidak dibuat secara khusus tetapi dicatat dalam berita acara seperti diatur dalam pasal 203 ayat 3 huruf d KUHAP. Sedangkan isi putusan praperadilan seperti diatur pada 
pasal 82 ayat 2 dan ayat 3. Selain memuat alasan dasar pertimbangan hukum oleh hakim petepatan atau putusan praperadilan juga harus memuat amar perintah.

\section{Simpulan}

Dari uraian diatas dapat ditarik kesimpulan untuk menjawab perumusan masalah diatas adalah Pengaturan kewenangan pengadilan negeri memutus gugatan praperadilan sesuai dengan pasal 77 Kitab Undang-undang Hukum Acara Pidana mengatur tantang Sah atau tidaknya penangkapan, penahanan, penghentian penyidikan dan penuntutan serta ganti kerugian dan rehabilitasi. Dengan adanya putusan mahkamah konstitusi nomor 21/PUU-XII/2014 mengenai sah atau tidaknya penetapan tersangka diharapkan dapat memberikan perlindungan terhadap hak asasi menambah wewenang yang diberikan kepad lembaga praperadilan. Sehingga seseorang yang ditetapkan sebagai tersangka dapat mengajukan gugatan praperadilan kepada aparat penegak hukum yang bertindak tidak sesuai dengan aturan yang berlaku.

Tata cara pemeriksaan sidang praperadilan merupakan permasalahan yang bersifat formil akibat dari adanya suatu tindakan yang dilakukan oleh penyidik atau penuntut umum. Namun dapat disampaikan tata cara dalam pengajuan gugatan praperadilan ke Pengadilan Negeri yakni, pengajuan permohonan praperadilan, permohonan registrasi dalam perkara praperadilan, penunjukan hakim dan panitera oleh ketua pengadilan Negeri, pemeriksaan praperadilan dilakukan oleh Hakim tunggal.

Lembaga penegak hukum, dalam hal ini kepolisian sebagai salah satu lembaga penegak keadilan harus dijalankan oleh aggotanya dengan bertanggung jawab dan dilaksanakan dengan sepenuh hati serta sesuai dengan peraturan yang perundang-undangan. KUHAP telah mengatur mengenai system dari penyelidikan, penyidikan, dan sampai pada proses sidang dimuka peradilan, hal ini harus dipatuhi dan diikuti sehingga tidak adanya kesalahan terutama sampai harus adanya pengajuan gugatan praperadilan;

Masyarakat sebegai subyek yang mendapat perlindungan hukum harus memiliki sifat kritis dan mengetahui tata cara melakukan pengajuan gugatan praperadilan untuk melindungi hakhaknya apabila berurusan dengan proses praperadilan. Hal ini penting guna menjaga martabat dan harkat sebagai manusia dalam proses penegakan hukum yang adil.

\section{Daftar Pustaka}

Harahap, Y. (2016). Pembahasan Permasalahan Dan Penerapan KUHAP Penyidikan dan Penuntutan, Edisi Kedua. Jakarta: Sinar Grafika.

Nugroho, H. S. (2020). Kewenangan Lembaga Pengadilan Dalam Menetapkan Sah Atau Tidaknya Status Tersangka Kasus Korupsi Di Sidang Praperadilan. Jurnal Verstek, 8(1), 148-156. Retrieved from https://jurnal.uns.ac.id/verstek/article/ view/39622

Prints, D. (1993). Praperadilan dan Perkembangannya Di Dalam Praktek. Bandung: Citra Aditya Bakti.

Prints, D. (2002). Hukum Acara Pidana Dalam Prakte. Jakarta: Djambatan.

Rahman, Z. (2015). Kewenangan Praperadilan Pasca Putusan Mahkamah Konstitusi. Jurnal RechtsVinding. Retrieved from https://rechtsvinding.bphn.go.id/ jurnal_online/Praperadilan $\%$ 20Tersangka\%207\%20Juli\%202015\% 20kirim-1.pdf 